\title{
Dry Storage Effects on Postharvest Performance of Selected Cut Flowers
}

\author{
Iftikhar Ahmad ${ }^{1,2,3}$, John M. Dole², Atyab Amjad ${ }^{1}$, and \\ Sagheer Ahmad ${ }^{1}$
}

AdDitional INDEX WORDS. Eustoma grandiflorum, Rosa bybrida, specialty cut species, Tagetes erecta, vase life, Zinnia elegans

\begin{abstract}
SUMMARY. Effects of wet and dry storage methods were compared to improve postharvest performance of specialty cut flower species. While increasing duration of storage reduced vase life, vase life declined less with dry storage for marigold (Tagetes erecta) and rose (Rosa bybrida), but not for zinnia (Zinnia elegans) or lisianthus (Eustoma grandiflorum) over wet storage. Marigold stems had 1.9, 4.6, and 1.5 days longer vase life after 1,2 , or 3 weeks in dry storage, respectively, as compared with storage in water. Zinnia stems did not tolerate either wet or dry storage, while lisianthus stems had a longer vase life when stored in water as compared with dry storage. For rose, dry storage for 2 weeks increased vase life compared with wet storage. Dry stored marigold and lisianthus stems had higher water uptake after being placed in the vase as compared with the stems stored in water, while zinnia and rose had less uptake. Storage method had no effect on leaf relative water content (LRWC) in lisianthus, marigold, and zinnia; however, LRWC decreased with increased storage duration. This necessitates evaluation of storage method and duration effects for each species and cultivar to ensure extended storage life and improve postharvest quality.
\end{abstract}

$\mathrm{C}$ ut flowers are highly perishable and complex plant organs that need to be properly handled and stored to preserve their value and quality (Reid, 2002). In some species, quality may be lost due to foliage or petal abscission, leaf chlorosis, geotropic stem bending, excessive respiration/transpiration, or storage/ handling at high temperatures (Joyce, 1988; Maxie et al., 1973; Reid, 2002). To slow down senescence, storage facilities must be available and storage methods well planned before harvest to preserve product quality during handling and transit and reduce transportation cost (Jones and Moody, 1993; Macnish et al., 2009a). Appropriate cut flower storage facilities also allow product to be accumulated for holidays and special events, when demand exceeds supply, to increase profitability.

Cut stems placed in water will develop a negative water balance when

The authors are grateful to Waqar Flower Land (Pattoki, Pakistan) and Peregrine Farm (Graham, NC) for provision of rose and lisianthus stems, respectively, and Dr. A.U. Malik, Professor, Postharvest Horticulture, University of Agriculture, Faisalabad, Pakistan, for providing storage facility for rose studies.

${ }^{1}$ Institute of Horticultural Sciences, University of Agriculture, Faisalabad-38040, Pakistan

${ }^{2}$ Department of Horticultural Science, North Carolina State University, Raleigh, NC 27695

${ }^{3}$ Corresponding author. E-mail: iahmad3@ncsu.edu. water uptake is less than water loss. This situation is often the result of xylem plugging at the stem base (van Meeteren et al., 2006); however, time to develop a negative water balance varies among species. In chrysanthemum (Chrysanthemum morifolium), negative water balance can develop a few hours after putting stems in water. A negative balance can also develop rapidly in stems that are stored dry before placement in water because of air uptake by the cut stem end (van Doorn, 1990; van Meeteren, 1992). Although aspired air did not cause embolisms in dry-stored stems of some rose cultivars, cavitations in the xylem resulted in most of the rapid blockage observed in dry-stored stems (Loubaud and van Doorn, 2004; van Doorn, 1997). Water stress resulting from restricted water uptake in turn reduces the turgor-derived strength in cut stems (Burdett, 1970) leaving only structural strength to keep stems upright. Turgor loss can also be caused by physiological plugging (Durkin and Kuc, 1966), microbial stem occlusion (Aarts, 1957), or a general physiological decline (Rasmussen and Carpenter, 1974).

Both dry and wet storage have advantages and disadvantages for cut stem storage and longevity. Generally, for long term, stems should be stored dry, while for shorter periods ( $1-4$ weeks), storage in water or a preservative solution is preferred (Reid, 2002; Sacalis, 1993). Dry storage saves space in coolers by allowing more stems to be stored in a small space; however, dry storage can be more labor intensive and costly because of packing and the need to recut stems after storage. Moreover, some species do not adapt well to dry storage; for example, dahlia (Dablia hybrids), freesia (Freesia bybrida), gerbera (Gerbera jamesonii), and gypsophila (Gypsophila elegans) (Nowak and Rudnicki, 1990). Species prone to botrytis (Botrytis cinerea) should be properly treated with fungicide and tissue surfaces dried before storage. Sometimes, pulsing with sugars, antimicrobials, antiethylene substances, or both can maintain flower quality throughout the storage period (Arboleda, 1993; Halevy and Mayak, 1981).

Wet storage of cut flowers is also widely practiced as flowers do not need to be packed and stems maintain good turgor. On the other hand, more space is used by the storage buckets, stems can deplete food reserves rapidly, and buds can open more quickly. Finally, wet storage provides more opportunities for pathogenic contamination, resulting in plugged stem ends, blocked water uptake, accelerated wilting, and ultimately death of the stems (Macnish et al., 2009b; Nell and Reid, 2000). Many researchers feel that the negative effects of water storage are so great that stems should remain dry entirely from harvest until receipt by the retailer and that any hydration of

\begin{tabular}{llll}
\hline $\begin{array}{l}\text { Units } \\
\begin{array}{l}\text { To convert U.S. to SI, } \\
\text { multiply by }\end{array}\end{array}$ & U.S. unit & SI unit & $\begin{array}{l}\text { To convert SI to U.S., } \\
\text { multiply by }\end{array}$ \\
\hline 29.5735 & $\mathrm{fl} \mathrm{oz}$ & $\mathrm{mL}$ & 0.0338 \\
2.54 & inch $(\mathrm{es})$ & $\mathrm{cm}$ & 0.3937 \\
1 & $\mathrm{mmho} / \mathrm{cm}$ & $\mathrm{dS} \cdot \mathrm{m}^{-1}$ & 1 \\
28.3495 & $\mathrm{oz}$ & $\mathrm{g}$ & 0.0353 \\
$\left({ }^{\circ} \mathrm{F}-32\right) \div 1.8$ & ${ }^{\circ} \mathrm{F}$ & ${ }^{\circ} \mathrm{C}$ & $\left(1.8 \times{ }^{\circ} \mathrm{C}\right)+32$
\end{tabular}


the stems in the marketing chain accelerates bacterial contamination and stem plugging (de Witte and van Doorn, 1988; van Doorn and D'hont, 1994; Zagory and Reid, 1986). Few studies have been conducted to determine if this practice is commercially practical and improves postharvest performance. This study was conducted to compare the effectiveness of wet vs. dry storage in maintaining quality and vase life extension of two of the most important U.S. fieldgrown specialty cut species (lisianthus and zinnia) and two of the most important Pakistan cut flower species (rose and marigold).

\section{Materials and methods}

Cut 'Double Eagle' marigold and 'Deep Red' zinnia were grown in the field at North Carolina State University (NCSU), Raleigh, while cut 'ABC Purple' lisianthus and 'Kardinal' and 'Angelique' roses were received from commercial flower producers (Peregrine Farm, Graham, NC and Waqar Flower Land, Pattoki, Pakistan, respectively). Lisianthus, marigold, and zinnia experiments were conducted at NCSU and the rose experiment at Institute of Horticultural Sciences, University of Agriculture, Faisalabad, Pakistan. On harvest/arrival, stems were sorted according to stage of development, stem caliper and head size and then distributed into groups of 25 stems (for rose studies, 15 stems) with each group containing a similar number of stems with the same characteristics. Stems were recut to $35 \mathrm{~cm}$ (except lisianthus, which was recut to $50 \mathrm{~cm}$ ), labeled, placed in either standard cardboard floral boxes having $100 \times 22.5 \times 18 \mathrm{~cm}$ dimensions lined with newspaper or in buckets containing tap water and placed into a cooler at $2 \pm 1{ }^{\circ} \mathrm{C}$, except for the control treatment stems that were put in vases containing $300 \mathrm{~mL}$ of tap water in a postharvest evaluation room without storage. Stems were stored for 1, 2, or 3 weeks dry or wet and recut after storage removing the lower 3 to $5 \mathrm{~cm}$. Each treatment had five replicates of three stems per vase for vase life and other parameters and two additional stems were included in each replication for LRWC for lisianthus, marigold, and zinnia. Vases with cut stems were arranged on benches in completely randomized designs in a postharvest evaluation room maintained at $20 \pm 2{ }^{\circ} \mathrm{C}$ and $40 \%$ to $60 \%$ relative humidity under a photosynthetically active radiation flux of $20 \mu \mathrm{mol} \cdot \mathrm{m}^{-2} \cdot \mathrm{s}^{-1}$ at bench level from white fluorescent tubes on a daily 12 -h photoperiod.

Data collected included vase life (time period from placing stems in vases until they were ended), prestorage initial fresh weight, poststorage fresh weight, termination fresh and dry weight (one stem per vase), water uptake [volume of vase water taken by stems measured $24 \mathrm{~h}$ (day l) after placing stems in vase and again $48 \mathrm{~h}$ (day 3 ) after the first measurement], final solution $\mathrm{pH}$ and $\mathrm{EC}(\mathrm{EC})$, initial and final (at termination) number of buds and flowers (lisianthus only), flower opening at day 7 of vase life (rose only), and reasons for termination. Reasons for termination were recorded for every stem as present or not present and included petal blackening, wilting, bent neck; leaf wilting and/or bud drying, depending on the species. The condition was recorded as present if it occurred on at least one petal, leaf, or bud. The LRWC was determined on days 0 and 7 (five stems/treatment) of vase life for marigold, zinnia, and lisianthus following the method described by Barr and Weatherley (1962). Initial solution $\mathrm{pH}$ and EC were 6.4 and $0.26 \mathrm{dS} \cdot \mathrm{m}^{-1}$ for lisianthus, 6.3 and $0.29 \mathrm{dS} \cdot \mathrm{m}^{-1}$ for marigold, 7.4 and $1.16 \mathrm{dS} \cdot \mathrm{m}^{-1}$ for rose, and 6.2 and $0.28 \mathrm{dS} \cdot \mathrm{m}^{-1}$ for zinnia. Analysis of variance on data was performed using the general linear model program of the SAS (version 9.1; SAS Institute, Cary, NC). Means were separated using the least significance difference test at $P \leq 0.05$. The experiments were repeated using the same cultivars of marigold and zinnia, but different cultivars of rose. Experiments with lisianthus were not repeated because of limited plant material.

\section{Results}

Lisianthus. Lisianthus had a longer vase life when stored in water than when stored dry (Table 1). Wetstored stems had higher fresh weight after storage, which decreased during the vase life. Dry-stored stems lost weight during storage, but regained a portion of the lost weight during the vase life. Wet storage promoted continued growth as witnessed by an increased number of buds (3.4 buds) after all storage durations.
Unfortunately, most of these buds were wilted because of loss of turgor and abscised at the beginning of vase life, resulting in a net loss of buds to 2.8 buds at termination for all storage durations. Such an effect was not observed in dry stored stems, which had more buds at termination (3.7 buds) than poststorage (3.1 buds) and retained them. Most of stems were ended because of petal wilt, petal blackening, bent neck, and bud drying during vase life. No significant difference occurred because of storage method on flower bud opening, bent neck, petal blackening, or bud drying during vase life, which averaged 0.8 (0-4 scale), $61 \%, 87 \%$, and $39 \%$ of stems, respectively (data not presented). Dry-stored stems had higher water uptake on day 1 than wet-stored stems; however, on day 3 , storage method had no effect (Table 1).

In lisianthus, storage duration had no effect on LRWC at day 0; however, those stems stored in water tended to have higher LRWC than dry stored stems (Table 2). After 7 $\mathrm{d}$ in the vase solution, the significant effect of storage method had disappeared, but the longest storage duration now resulted significantly in the lowest LRWC.

MARIGOLD. Marigold was quite tolerant of dry storage. Stems stored dry had 1.9, 4.6, and $1.5 \mathrm{~d}$ longer vase life than those stored wet after 1, 2, or 3 weeks storage, respectively, with vase life declining more slowly with increasing duration when stems were stored dry (Table 3). Except where indicated, similar results were recorded when the experiment was repeated (data not presented). After storage, dry-stored stems had lower fresh weight $(11.8 \mathrm{~g})$ than wet stored stems (17.7 g) (data not shown). Dry-stored stems lost fresh weight during storage, but maintained weight during the vase life. Conversely, wet-stored marigold had higher poststorage fresh weight that decreased rapidly during the vase life (Table 3). Petal wilting and petal blackening were major reasons, and bent neck a lesser cause, of vase life termination. No significant difference occurred because of storage method on petal wilting, petal blackening, or bent neck, which averaged $100 \%, 51 \%$, and $14 \%$ of stems, respectively (data not presented). Interestingly, however, most of the unstored and l-week 
Table 1. Effect of storage method and duration on vase life, fresh weight changes, bud change, and water uptake of 'ABC Purple' lisianthus. Prepared stems were placed either in standard cardboard floral boxes (dry storage) or in buckets with stem ends in tap water (wet storage) and placed in a cooler at $2 \pm 1{ }^{\circ} \mathrm{C}\left(35.6 \pm 1.8{ }^{\circ} \mathrm{F}\right)$ for 1,2 , or 3 weeks. After storage, stems were recut to $30 \mathrm{~cm}$ ( 11.8 inches ) and placed in vases containing $300 \mathrm{~mL}(10.1 \mathrm{fl} \mathrm{oz})$ tap water with three stems per vase and held at $20 \pm 2{ }^{\circ} \mathrm{C}\left(68 \pm 3.6^{\circ} \mathrm{F}\right)$. Unstored stems were recut and placed in vases immediately after receipt. Means are an average of data from five replicate vases, with three stems each.

\begin{tabular}{|c|c|c|c|c|c|c|c|}
\hline \multicolumn{2}{|c|}{ Storage treatments } & \multirow[b]{2}{*}{ Vase life $(\mathrm{d})$} & \multirow{2}{*}{$\begin{array}{c}\text { Storage fresh } \\
\text { wt change }(\mathrm{g})^{\mathrm{z}}\end{array}$} & \multirow{2}{*}{$\begin{array}{c}\text { Vase fresh } \\
\text { wt change }(\mathrm{g})\end{array}$} & \multirow{2}{*}{$\begin{array}{l}\text { Change in } \\
\text { no. buds }\end{array}$} & \multirow{2}{*}{$\begin{array}{c}\text { Water uptake day } 1 \\
\text { of vase life }(\mathrm{mL})^{\mathrm{z}}\end{array}$} & \multirow{2}{*}{$\begin{array}{c}\text { Water uptake day } 3 \\
\text { of vase life }(\mathrm{mL})\end{array}$} \\
\hline Method & Duration (wk) & & & & & & \\
\hline Unstored & 0 & $10.9 \mathrm{a}^{\mathrm{x}}$ & - & $-6.2 \mathrm{a}$ & $-1.0 \mathrm{a}$ & $36.6 \mathrm{bcd}$ & $68.0 \mathrm{a}$ \\
\hline & 2 & $6.4 \mathrm{c}$ & $-7.0 \mathrm{~b}$ & $2.5 \mathrm{c}$ & $0.3 \mathrm{bc}$ & $42.8 \mathrm{abc}$ & $48.4 \mathrm{bc}$ \\
\hline & 3 & $3.2 \mathrm{e}$ & $-10.4 \mathrm{a}$ & $4.5 \mathrm{c}$ & $0.6 \mathrm{c}$ & $49.6 \mathrm{a}$ & $31.8 \mathrm{~d}$ \\
\hline Wet & 1 & $8.5 \mathrm{~b}$ & $1.4 \mathrm{~d}$ & $-8.4 \mathrm{a}$ & $-0.3 \mathrm{ab}$ & $26.2 \mathrm{de}$ & $58.2 \mathrm{ab}$ \\
\hline \multirow[t]{4}{*}{ Significance ${ }^{w}$} & Overall & $<0.0001$ & $<0.0001$ & $<0.0001$ & 0.0005 & 0.0008 & 0.0002 \\
\hline & Method (M) & 0.0005 & $<0.0001$ & $<0.0001$ & 0.0001 & $<0.0001$ & NS \\
\hline & Duration (D) & $<0.0001$ & $<0.0001$ & 0.0060 & NS & NS & 0.0004 \\
\hline & $\mathrm{M} \times \mathrm{D}$ & NS & 0.0020 & 0.2349 & NS & NS & NS \\
\hline
\end{tabular}

${ }^{\mathrm{z}} \mathrm{l} \mathrm{g}=0.0353 \mathrm{oz}, \mathrm{l} \mathrm{mL}=0.0338 \mathrm{floz}$.

yumber of buds when stem was placed in the vase - number of buds at vase life termination.

${ }^{\mathrm{x}}$ Means followed by the same letter are not significantly different according to least significant difference test at $\alpha \leq 0.05$.

wProbability values were obtained using the General Linear Models (GLM) procedure of SAS (version 9.1; SAS Institute, Cary, NC) for significant effects of storage method and duration; Ns = not significant at $P>0.05$.

Table 2. Effect of storage method and duration on leaf relative water contents (LRWC) of 'ABC Purple' lisianthus, 'Double Eagle' marigold and 'Deep Red' Benary's Giant Series zinnia. Plant material was handled as described in Table 1. Means are an average of data from five replicate stems.

\begin{tabular}{|c|c|c|c|c|c|c|c|c|c|c|}
\hline \multicolumn{2}{|c|}{ Storage treatments } & \multicolumn{3}{|c|}{$\begin{array}{c}\text { Lisianthus } \\
\text { LRWC (\%) }\end{array}$} & \multicolumn{3}{|c|}{$\begin{array}{c}\text { Marigold } \\
\text { LRWC (\%) }\end{array}$} & \multicolumn{3}{|c|}{$\begin{array}{c}\text { Zinnia } \\
\text { LRWC (\%) }\end{array}$} \\
\hline Method & Duration (wk) & Day 0 & Day 7 & Change & Day 0 & Day 7 & Change & Day 0 & Day 7 & Change \\
\hline \multirow[t]{3}{*}{ Dry } & 1 & $59.3 \mathrm{~b}$ & $79.2 \mathrm{ab}$ & $19.9 \mathrm{c}$ & $57.3 \mathrm{~b}$ & 72.4 & 15.1 & $52.5 \mathrm{ab}$ & $50.8 \mathrm{a}$ & $-1.7 \mathrm{~b}$ \\
\hline & 2 & $63.6 \mathrm{ab}$ & $73.8 \mathrm{ab}$ & $10.2 \mathrm{bc}$ & $78.3 \mathrm{ab}$ & 76.6 & -1.7 & - & - & - \\
\hline & 3 & $54.0 \mathrm{~b}$ & $53.3 \mathrm{~b}$ & $-0.7 \mathrm{ab}$ & $70.6 \mathrm{ab}$ & $-\mathrm{y}$ & - & 一 & 一 & - \\
\hline & 3 & $77.2 \mathrm{a}$ & $66.4 \mathrm{ab}$ & $-10.8 \mathrm{a}$ & $103.0 \mathrm{a}$ & - & - & $21.6 \mathrm{~b}$ & - & - \\
\hline \multirow[t]{4}{*}{ Significance $^{x}$} & Overall & 0.0005 & 0.0314 & 0.0414 & 0.0015 & NS & NS & 0.0064 & $<0.0001$ & 0.0005 \\
\hline & Method (M) & $<0.0001$ & NS & NS & 0.0302 & NS & NS & NS & NS & NS \\
\hline & Duration (D) & NS & 0.0051 & 0.0112 & 0.0262 & NS & NS & 0.0012 & $<0.0001$ & 0.0011 \\
\hline & $\mathrm{M} \times \mathrm{D}$ & NS & NS & NS & 0.0377 & NS & NS & - & - & - \\
\hline
\end{tabular}

${ }^{\mathrm{z}}$ Means followed by the same letter are not significantly different according to least significant difference test at $\alpha \leq 0.05$.

y Flowers died before data collection.

xProbability values were obtained using the General Linear Models (GLM) procedure of SAS (version 9.1; SAS Institute, Cary, NC) for significant effects of storage method and duration; Ns = not significant at $P>0.05$.

stored stems developed roots at their stem ends in both experiments, while stems stored for 2 or 3 weeks either had no or only very small roots (personal observation). With increasing storage duration, wet-stored stems had less water uptake than dry stored stems after being placed in the vase (Table 3); however, when the experiment was repeated, all stored stems had similar water uptake. Storage method had no effect of water uptake.

On day 0 in the vase, stored stems had higher LRWC than unstored and those stored in water had higher LRWC than dry stored (Table 2). Neither LRWC at day 7 nor the change in water content was statistically significant, which might have been due to reduced number of replications because of loss of stems that died before $7 \mathrm{~d}$ in the vase. However, during the vase life, LRWC tended to decrease for wet-stored stems and increase for drystored stems.

Rose. Cut 'Kardinal' and 'Angelique' rose tolerated dry storage and both cultivars had an acceptable vase life of $5 \mathrm{~d}$ or more (except for 1 week storage of 'Angelique') (Table 4). For stems stored for $1-3$ weeks, wet storage produced a vase life of $6 \mathrm{~d}$ or more. Dry stored 'Kardinal' and 'Angelique' stems lost fresh weight during storage, while wet-stored stems gained weight; however, wet-stored stems lost more weight during the vase life than those held in dry storage. In both rose cultivars, stems were ended because of petal wilt and bent neck with foliage wilting in 3-week stored stems. With 'Angelique', wetstored stems initially had higher water uptake than dry-stored stems (week 1); 
Table 3. Effect of storage method and duration on vase life, fresh weight changes, and water uptake of 'Double Eagle' African Gold Coin Series marigold. Plant material was handled as described in Table 1.

\begin{tabular}{|c|c|c|c|c|c|c|}
\hline \multicolumn{2}{|c|}{ Storage treatments } & \multirow[b]{2}{*}{ Vase life $(d)$} & \multirow{2}{*}{$\begin{array}{c}\text { Storage fresh } \\
\text { wt change }(g)^{\mathrm{z}}\end{array}$} & \multirow{2}{*}{$\begin{array}{c}\text { Vase fresh } \\
\text { wt change }(\mathrm{g})\end{array}$} & \multirow{2}{*}{$\begin{array}{l}\text { Water uptake day } 1 \\
\text { of vase life }(\mathrm{mL})^{\mathrm{z}}\end{array}$} & \multirow{2}{*}{$\begin{array}{c}\text { Water uptake day } 3 \\
\text { of vase life }(\mathrm{mL}) \\
\end{array}$} \\
\hline Method & Duration (wk) & & & & & \\
\hline Unstored & 0 & $13.3 \mathrm{a}^{\mathrm{y}}$ & - & $-1.2 \mathrm{bc}$ & $25.4 \mathrm{bc}$ & $29.2 \mathrm{a}$ \\
\hline & 2 & $9.3 \mathrm{~b}$ & $-3.3 b$ & $-0.6 \mathrm{bc}$ & $19.6 \mathrm{~cd}$ & $18.2 \mathrm{c}$ \\
\hline & 3 & $2.9 \mathrm{~cd}$ & $-5.8 \mathrm{a}$ & $0.0 \mathrm{c}$ & $16.6 \mathrm{~cd}$ & $19.0 \mathrm{c}$ \\
\hline Wet & 1 & $9.7 \mathrm{~b}$ & $2.9 \mathrm{e}$ & $-4.6 \mathrm{a}$ & $29.4 \mathrm{ab}$ & $23.6 \mathrm{~b}$ \\
\hline \multirow[t]{4}{*}{ Significance $^{w}$} & Overall & $<0.0001$ & $<0.0001$ & $<0.0001$ & 0.0003 & $<0.0001$ \\
\hline & Method (M) & $<0.0001$ & $<0.0001$ & $<0.0001$ & NS & NS \\
\hline & Duration (D) & $<0.0001$ & $<0.0001$ & 0.0364 & $<0.0001$ & 0.0021 \\
\hline & $\mathrm{M} \times \mathrm{D}$ & 0.0421 & NS & NS & NS & NS \\
\hline
\end{tabular}

${ }^{\mathrm{z}} \mathrm{l} \mathrm{g}=0.0353 \mathrm{oz}, \mathrm{l} \mathrm{mL}=0.0338 \mathrm{floz}$.

${ }^{y}$ Means followed by the same letter are not significantly different according to least significant difference test at $\alpha \leq 0.05$.

${ }^{x}$ Flowers died before data collection.

"Probability values were obtained using the General Linear Models (GLM) procedure of SAS (version 9.1; SAS Institute, Cary, NC) for significant effects of storage method and duration; NS = not significant at $P>0.05$

Table 4. Effect of storage method and duration on vase life, fresh weight changes, and water uptake of 'Kardinal' and 'Angelique' cut rose. Plant material was handled as described in Table 1.

\begin{tabular}{|c|c|c|c|c|c|c|c|c|c|}
\hline \multicolumn{2}{|c|}{ Storage treatments } & \multicolumn{2}{|c|}{ Vase life $(d)$} & \multicolumn{2}{|c|}{$\begin{array}{c}\text { Storage fresh } \\
\text { wt change }(\mathrm{g})^{\mathrm{z}}\end{array}$} & \multicolumn{2}{|c|}{$\begin{array}{c}\text { Vase fresh } \\
\text { wt change }(\mathrm{g})\end{array}$} & \multicolumn{2}{|c|}{ Water uptake $(\mathrm{mL})^{\mathrm{z}}$} \\
\hline Method & Duration (wk) & 'Kardinal' & 'Angelique' & 'Kardinal' & 'Angelique' & 'Kardinal' & 'Angelique' & 'Kardinal' & 'Angelique' \\
\hline \multirow[t]{3}{*}{ Dry } & 1 & $6.7 \mathrm{~cd}$ & $4.0 \mathrm{~d}$ & $-1.6 \mathrm{ab}$ & $-0.9 \mathrm{~b}$ & $-0.3 \mathrm{~d}$ & $-0.2 \mathrm{~b}$ & $57.6 \mathrm{bc}$ & $19.2 \mathrm{~d}$ \\
\hline & 2 & $7.8 \mathrm{bc}$ & $9.1 \mathrm{~b}$ & $-1.0 \mathrm{ab}$ & $-6.5 \mathrm{a}$ & $-1.9 \mathrm{~cd}$ & $-1.5 \mathrm{~b}$ & $53.6 \mathrm{c}$ & $52.0 \mathrm{~b}$ \\
\hline & 3 & $5.5 \mathrm{~d}$ & $7.4 \mathrm{c}$ & $-2.9 \mathrm{a}$ & $-2.2 \mathrm{ab}$ & $-0.7 \mathrm{~d}$ & $-1.7 \mathrm{~b}$ & $27.6 \mathrm{~d}$ & $30.8 \mathrm{c}$ \\
\hline & 3 & $6.6 \mathrm{~cd}$ & $7.5 \mathrm{c}$ & $2.6 \mathrm{c}$ & $0.5 \mathrm{~b}$ & $-5.5 \mathrm{a}$ & $-4.5 \mathrm{a}$ & $33.0 \mathrm{~d}$ & $28.0 \mathrm{~cd}$ \\
\hline \multirow[t]{4}{*}{ Significance $^{x}$} & Overall & $<0.0001$ & $<0.0001$ & NS & 0.0183 & 0.0001 & $<0.0001$ & $<0.0001$ & $<0.0001$ \\
\hline & Method (M) & NS & 0.0168 & 0.0227 & 0.0042 & $<0.0001$ & $<0.0001$ & 0.0332 & $<0.0001$ \\
\hline & Duration (D) & 0.0012 & 0.0257 & NS & NS & NS & NS & $<0.0001$ & $<0.0001$ \\
\hline & $\mathrm{M} \times \mathrm{D}$ & 0.0295 & $<0.0001$ & NS & NS & 0.0239 & NS & NS & $<0.0001$ \\
\hline
\end{tabular}

${ }^{\mathrm{z}} \mathrm{l} \mathrm{g}=0.0353 \mathrm{oz}, \mathrm{lmL}=0.0338 \mathrm{fl} \mathrm{oz}$.

${ }^{\mathrm{y}}$ Means followed by the same letter are not significantly different according to least significant difference test at $\alpha \leq 0.05$.

x Probability values were obtained using the General Linear Models (GLM) procedure of SAS (version 9.1; SAS Institute, Cary, NC) for significant effects of storage method and duration; NS $=$ not significant at $P>0.05$.

however, this difference decreased when stems were stored for 2 or 3 weeks.

Storage method had no effect on flower opening, which, however, was greatest when flowers were stored for 3 weeks (Table 5). Leaf wilting only occurred with 3 weeks storage, except for dry storage of 'Angelique', which had no leaf wilting. In both cultivars, no significant difference occurred because of storage method on petal wilting, which averaged $81 \%$ and $82 \%$ in 'Kardinal' and 'Angelique', respectively (data not presented). Storage method had no effect on bent neck, but longer storage duration reduced bent neck incidence, particularly in 'Angelique' rose. Percentage of stems with bent neck was reduced from $90 \%$ to $67 \%$ and $77 \%$ to $57 \%$ on average in
1-3 weeks stored 'Angelique' and 'Kardinal' stems, respectively (data not presented).

ZINNIA. Zinnia did not tolerate dry storage as indicated by a 3.8-d vase life after only 1 week in dry storage, which was $9.6 \mathrm{~d}$ less than unstored flowers (Table 6). Similar results occurred when the experiment was repeated (data not presented). In fact, zinnia did not appear to tolerate storage longer than 1 week regardless of the storage method. At the end of storage, wet-stored stems had higher fresh weight as compared with their initial weight, while dry-stored stems lost weight during storage directly in proportional to the length of the storage period. However, during the vase life, wet-stored stems lost more weight than did the dry-stored stems. Zinnia stems were ended because of petal wilt, stem collapse, petal drying, petal blackening, and petal fading. Dry-stored stems had less petal blackening and wilting, but more stem collapse as compared with wet storage. Moreover, stem collapse and petal blackening increased with extending storage period (Table 6). Similar results occurred when the experiment was repeated (data not presented). No significant difference occurred because of storage method on petal fading, which averaged $84 \%$ of stems (data not presented).

Wet-stored stems had higher water uptake than dry-stored stems (Table 6). When the experiment was repeated, storage duration reduced 
Table 5. Effect of storage method and duration on flower opening and leaf wilting of 'Kardinal' and 'Angelique' cut rose. Plant material was handled as described in Table 1.

\begin{tabular}{|c|c|c|c|c|c|}
\hline \multicolumn{2}{|c|}{ Storage treatments } & \multicolumn{2}{|c|}{ Flower opening $(\%)^{\mathrm{z}}$} & \multicolumn{2}{|c|}{ Leaf wilting $(\%)^{\mathrm{z}}$} \\
\hline Method & Duration (wk) & 'Kardinal' & 'Angelique' & 'Kardinal' & 'Angelique' \\
\hline Unstored & 0 & $13 \mathrm{~d}^{\mathrm{y}}$ & $47 \mathrm{~b}$ & $0 \mathrm{c}$ & $0 \mathrm{~b}$ \\
\hline \multirow[t]{3}{*}{ Dry } & 1 & $40 \mathrm{c}$ & $40 \mathrm{bc}$ & $0 \mathrm{c}$ & $0 \mathrm{~b}$ \\
\hline & 2 & $0 \mathrm{~d}$ & $13 \mathrm{~cd}$ & $0 \mathrm{c}$ & $0 \mathrm{~b}$ \\
\hline & 3 & $73 \mathrm{~b}$ & $33 \mathrm{bcd}$ & $60 \mathrm{~b}$ & $0 \mathrm{~b}$ \\
\hline \multirow[t]{3}{*}{ Wet } & 1 & $7 \mathrm{~d}$ & $13 \mathrm{~cd}$ & $0 \mathrm{c}$ & $0 \mathrm{~b}$ \\
\hline & 2 & $40 \mathrm{c}$ & $7 \mathrm{~d}$ & $0 \mathrm{c}$ & $0 \mathrm{~b}$ \\
\hline & 3 & $100 \mathrm{a}$ & $80 \mathrm{a}$ & $80 \mathrm{a}$ & $80 \mathrm{a}$ \\
\hline \multirow[t]{4}{*}{ Significance $^{\mathrm{x}}$} & Overall & $<0.0001$ & $<0.0001$ & $<0.0001$ & $<0.0001$ \\
\hline & Method (M) & NS & NS & NS & $<0.0001$ \\
\hline & Duration (D) & $<0.0001$ & 0.0002 & $<0.0001$ & $<0.0001$ \\
\hline & $\mathrm{M} \times \mathrm{D}$ & 0.0003 & 0.0083 & NS & $<0.0001$ \\
\hline
\end{tabular}

${ }^{2}$ Percentage of stems exhibiting problem.

${ }^{y}$ Means followed by the same letter are not significantly different according to least significant difference test at $\alpha \leq 0.05$.

xProbability values were obtained using the General Linear Models (GLM) procedure of SAS (version 9.1; SAS Institute, Cary, NC) for significant effects of storage method and duration; Ns = not significant at $P>0.05$.

water uptake; however, storage method did not influence uptake. All 2 and 3 week dry-stored and 3 week wet-stored stems were dead at the end of storage. On day 0 in the vase, wet-stored stems had higher LRWC than dry-stored and unstored stems (Table 2). On day 7, LRWC of unstored stems increased, that of 1 -week stored stems was almost similar, while 2 week wet-stored stems LRWC decreased; however, it could not be compared with dry-stored stems, because the latter all were already dead.

\section{Discussion}

Proper storage of cut flowers is a vital handling step that ensures maintenance of desired maturity stage, original flower color and turgor (J.F. Thompson and M.S. Reid, unpublished data). Hydration of cut flowers after harvest is customary to restore flower turgidity lost during handling and storage and is also required to reduce water deficit stress caused by subsequent dry transportation (van Doorn, 1997). Moreover, hydration ensures continued petal expansion and flower opening of cut flowers (Evans and Reid, 1988). Unfortunately, if done immediately after harvest, hydration can increase bacterial plugging of stems (Macnish et al., 2009b; van Doorn and de Witte, 1991; Zagory and Reid, 1986).

For some of the species tested here, our results support the hypothesis that dry handling has no negative effect on cut flowers longevity and quality. Marigold performed well with dry handling, and for rose dry handling produced similar results as wet handling; however, zinnia and lisianthus both performed poorly after dry storage. These results are consistent with the findings that dry storage is effective for extending longevity of some cut flowers, e.g., budcut carnations (Dianthus caryophyllus) up to 6 months (Goszczynska and Rudnicki, 1982; 1983; Halevy and Mayak, 1981) and stock (Matthiola incana) (Regan and Dole, 2010). Therefore, species that tolerate dry handling should be hydrated after storage, not before.

Weight loss of all species tested was higher during dry storage than during standard wet storage, where stems gained weight because of continuous water availability. However, wet-stored stems lost weight during the vase life, while dry-stored stems either gained weight or lost less weight than wet-stored stems. Drystored stems rehydrated quickly when placed in vase solutions. Thus, dry handling appears to result in more favorable water relations for rose during vase life than wet storage and similar vase life. However, unstored stems had higher water uptake but smaller fresh weight change except lisianthus stems which had higher fresh weight change. Rehydration of dry-stored stems of different species depends on diameter of embolized xylem vessels (van Ieperen et al.,
2002), preharvest growth conditions (Twumasi et al., 2005; van Meeteren et al., 2005), and replacement rate of aspired air by water, on placement of stems in water (van Ieperen et al., 2002). Plants grown in water-stressed conditions have better hydraulic conductance recovery after air aspiration than stems grown in well-watered condition, which might be due to their smaller average xylem diameter (van Meeteren et al., 2005). For specialty cut species, significantly higher water uptake rates relative to wet-stored stems suggest that dry handled stems may have less bacterial contamination than those stored wet (de Witte and van Doorn, 1988). The bacteria on stem ends and in contaminated solutions can enter xylem vessels during hydration or wet storage and plug the stems ends (van Doorn and de Witte, 1991). This not only reduces water uptake and longevity but also flower opening. Finally, dry handling benefits can be even greater if lower storage temperatures are maintained (Cevallos and Reid, 2001; Maxie et al., 1973). For marigold, storage in water caused more rapid, although statistically similar petal blackening and wilting at the end of vase life than in dry storage, which might be on account of greater continued metabolic activities and further floral development in wet storage. However, zinnia could not tolerate longer than 1 week storage irrespective of the storage method. Foliage wilting and lack of water uptake in zinnia have also been reported by Twumasi et al. (2005) even when stems were put in vases without storage. In addition to normal respiration, other sinks such as ovary or other floral organ development (Nichols and Ho, 1975a, 1975b) or development of new flowers and buds (Waithaka et al., 2001), may have caused translocation of metabolites from petals, ultimately resulting in rapid discoloring and wilting.

This study showed that storage in water is not necessary to avoid water loss in some species like marigold and rose. In summary, marigold and rose, but not zinnia and lisianthus, can be dry handled without any significant decrease in longevity. Moreover, the different species' specific responses to dry vs. wet storage seen here highlight the need to evaluate the effectiveness of dry handling on other species and cultivars. 


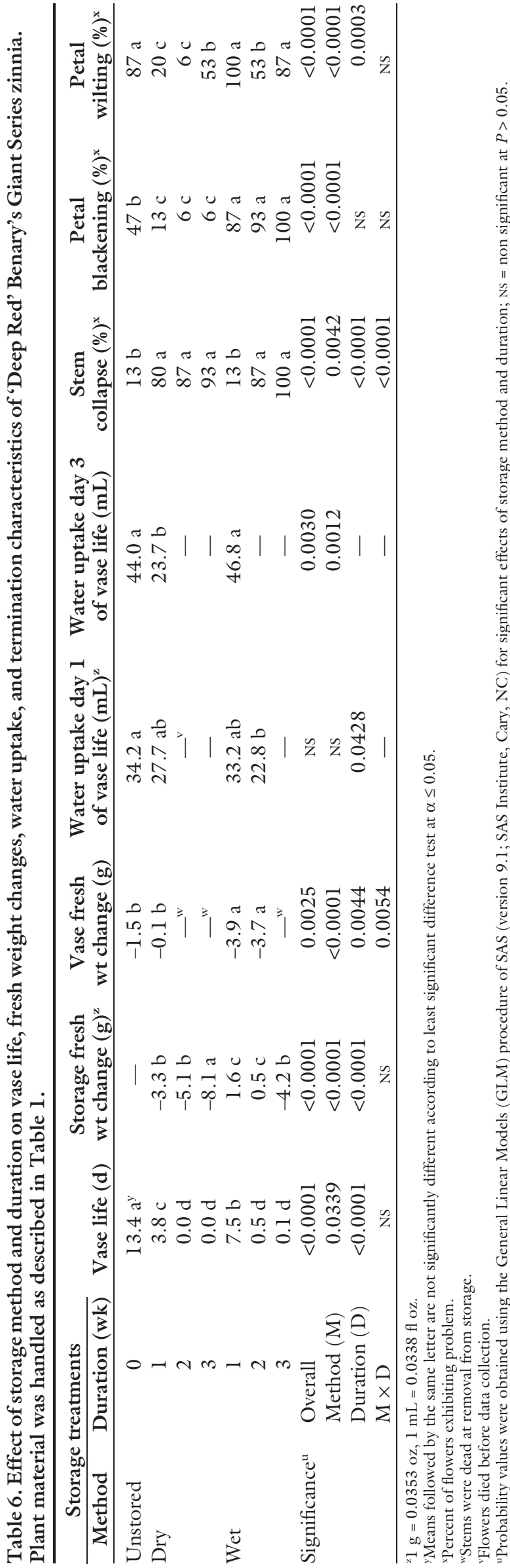

\section{Literature cited}

Aarts, J.F.T. 1957. Over de houdbaarheid van snijbloemen. Meded Landbouwhogeschool Wageningen 57:1-62.

Arboleda, P.J.A. 1993. Principios fundamentales de la postcosecha de flores, $\mathrm{p}$. 1-44. In: Tercer Seminario Técnico de Floricultura/EXPOFLOR 93. 11-14 June. Huixquilucan, State of Mexico, Mexico.

Barr, H.D. and P.E. Weatherley. 1962. A re-examination of the relative turgidity technique for estimating water deficit in leaves. Aust. J. Biol. Sci. 15:413-428.

Burdett, A.N. 1970. The cause of bent neck in cut roses. J. Amer. Soc. Hort. Sci. 95:427-431.

Cevallos, J.C. and M.S. Reid. 2001. Effect of dry and wet storage at different temperatures on the vase life of cut flowers. HortTechnology 11:199-202.

de Witte, Y. and W.G. van Doorn. 1988. Identification of bacteria in the vase water of roses, and the effect of the isolated strains on water uptake. Sci. Hort. 35:285291.

Durkin, D. and R. Kuc. 1966. Vascular blockage and senescence of cut rose flower. Proc. Amer. Soc. Hort. Sci. 89:683-688.

Evans, R.Y. and M.S. Reid. 1988. Changes in carbohydrates and osmotic potential during rhythmic expansion of rose petals. J. Amer. Soc. Hort. Sci. 113: 884-888.

Goszczynska, D.M. and R.M. Rudnicki. 1982. Long term storage of carnations cut at the green bud stage. Sci. Hort. 17:289297.

Goszczynska, D.M. and R.M. Rudnicki. 1983. Long-term storage of bud-cut carnations. Acta Hort. 141:203-212.

Halevy, A.H. and S. Mayak. 1981. Senescence and postharvest physiology of cut flowers. Part 2. Hort. Rev. 3:59-153.

Jones, R. and H. Moody. 1993. Caring for cut flowers. Agmedia, St. Kilda, Australia.

Joyce, D.C. 1988. Postharvest characteristics of geraldton wax flowers. J. Amer. Soc. Hort. Sci. 13:738-742.

Loubaud, M. and W.G. van Doorn. 2004. Wound-induced and bacteria induced xylem blockage in roses, Astilbe, and Viburnum. Postharvest Biol. Technol. 32:281-288.

Macnish, A.J., M.S. Reid, and D.C. Joyce. 2009a. Ornamentals and cut flowers, p. 491-506. In: E.M. Yahia (ed.). Modified and controlled atmospheres for the storage, transportation, and packaging of 
horticultural commodities. Taylor \& Francis Group, Boca Raton, FL.

Macnish, A.J., A. de Theije, M.S. Reid, and C.Z. Jiang. 2009b. An alternative postharvest handling strategy for cut flowers- Dry handling after harvest. Acta Hort. 847:215-221.

Maxie, E.C., D.S. Farnham, F.G. Mitchell, N.F. Sommer, R.A. Parsons, R.G. Snyder, and H.L. Rae. 1973. Temperature and ethylene effects on cut flowers of carnations (Dianthus caryophyllus). J. Amer. Soc. Hort. Sci. 98:568-572.

Nell, T.A. and M.S. Reid. 2000. Flower and plant care: The 21 st century approach. Society of American Florists, Alexandria, VA.

Nichols, R. and L.C. Ho. 1975a. An effect of ethylene on the distribution of 14C sucrose from the petals to other flower parts in the senescent cut inflorescence of Dianthus caryophyllus. Ann. Bot. 39:433438.

Nichols, R. and L.C. Ho. 1975b. Effects of ethylene and sucrose on translocation of dry matter and 14C sucrose in the cut flower of the glasshouse carnation (Dianthus caryophyllus) during senescence. Ann. Bot. 39:287-296.

Nowak, J. and R.M. Rudnicki. 1990. Postharvest handling and storage of cut flowers, florist greens and potted plants. Timber Press, Portland, OR.
Rasmussen, H.P. and W.J. Carpenter. 1974. Changes in the vascular morphology of cut rose stems: A scanning electron microscopy study. J. Amer. Soc. Hort. Sci. 99:454-495.

Regan, E.M. and J.M. Dole. 2010. Postharvest handling procedures of Matthiola incana 'Vivas Blue'. Postharvest Biol. Technol. 58:268-273.

Reid, M.S. 2002. Postharvest handling systems: Ornamental crops, p. 315-325. In: A.A. Kader (ed.). Postharvest technology of horticultural crops. University of California, Oakland.

Sacalis, J.N. 1993. Cut flowers: Prolonging freshness, p. 52-54. In: J.L. Seals. (ed.). Post production care and handling. 2nd ed. Ball Publ., Batavia, IL.

Twumasi, P., W. van Ieperen, E.J. Woltering, A.M.C. Emons, J.H.N. Schel, J.F.H. Snel, U. van Meeteren, and D. van Marwijk. 2005. Effects of water stress during growth on xylem anatomy, xylem functioning and vase life in three Zinnia elegans cultivars. Acta Hort. 669:303-312.

van Doorn, W.G. 1990. Aspiration of air at the cut surface of rose stems and its effect on the uptake of water. J. Plant Physiol. 137:160-164.

van Doorn, W.G. 1997. Water relations of cut flowers. Hort. Rev. 18:1-85.

van Doorn, W.G. and Y. de Witte. 1991. Effect of bacterial suspensions on vascular occlusion in stems of cut rose flowers. J. Appl. Bacteriol. 71:119-123.

van Doorn, W.G. and K. D'hont. 1994. Interaction between the effects of bacteria and dry storage on the opening and water relations of cut rose flowers. J. Appl. Bacteriol. 77:644-649.

van Ieperen, W., U. van Meeteren, and J. Nijsse. 2002. Embolism repair in cut flower stems: A physical approach. Postharvest Biol. Technol. 25:1-14.

van Meeteren, U. 1992. Role of air embolism and low water temperature in water balance of cut chrysanthemum flowers. Sci. Hort. 51:275-284.

van Meeteren, U., A. van Gelder, and W. Van Ieperen. 2005. Effect of growth conditions on postharvest rehydration ability of cut chrysanthemum flowers. Acta Hort. 669:287-296.

van Meeteren, U., L. Arévalo-Galarza, and W.G. van Doorn. 2006. Inhibition of water uptake after dry storage of cut flowers: Role of aspired air and woundinduced processes in Chrysanthemum. Postharvest Biol. Technol. 41:70-77.

Waithaka, K., L.L. Dodge, and M.S. Reid. 2001. Carbohydrate traffic during opening of gladiolus florets. J. Hort. Sci. Biotechnol. 76:120-124.

Zagory, D. and M.S. Reid. 1986. Role of vase solution microorganisms in the life of cut flowers. J. Amer. Soc. Hort. Sci. 111:154-158. 